\title{
Renovation, Gentrification, and Revitalisation of the Chinese Baroque Area in Harbin Lessons learned from a heritage-driven urban development project
}

\author{
Wenzhuo ZHANG, The Australian National University, Australia
}

\begin{abstract}
Harbin is a Chinese metropolis founded by the Russians in 1898. The Russian colonial rule brought European architecture to the city, in which context the Chinese Baroque architectural style - a hybrid of Baroque architecture and Chinese traditional architecture - was created. Today, Harbin, especially its Daowai District, still accommodates a constellation of Chinese Baroque buildings. An ongoing heritage-driven urban development project, which started in 2007, aims to revitalise the historic Daowai Chinese Baroque area by transforming it into one of the three largest tourist areas in Harbin. To carry out the plan, almost all the inhabitants of that area were relocated, despite discontent among the residents. While a small part of the area has been renovated/reconstructed and, in turn, gentrified and transformed into a tourist attraction, many historic Chinese Baroque buildings are still left vacant and even unattended to decay. With archival analysis, observation, and semi-structured interviews, this paper critically analyses the urban exclusion due to built heritage renovation and historic area revitalisation, and investigates the challenges that Harbin is now facing in its urban (re)development. It is argued that the dilemma faced by the Chinese Baroque project is fundamentally an economic problem rather than a cultural/social problem. Despite the significance of the Chinese Baroque buildings in terms of architecture, art, and history, the conservation, refurbishment, and promotion of the area are mainly of economic concern. To conclude, suggestions are made for a more inclusive future of the planning and management of the Chinese Baroque area.
\end{abstract}

\section{Keywords}

inhabitant relocation, community participation, cultural heritage, historic urban centre, tourism, China

\section{Introduction}

Harbin, the capital of Heilongjiang Province in Northeast China, is a young metropolis close to the Chinese border with Russia. Despite lengthy debates since the 1990s around the city's historical origins (Koga, 2008; Lahusen, 1998; Wolff, 1999), a consensus has been reached that the modern city of Harbin was founded by the Russians in 1898 (See for example: Gamsa, 2010; Xie et al., 2016), when the construction of the Russian-built Chinese Eastern Railway (CER) and its southern extension began under the terms of the 1896 Li-Lobanov Treaty and the 1898 Pavlov Agreement. As the Russian administrative centre of the railway and later an international treaty port, by the late 1920s, Harbin had boomed to be the largest commercial and logistics hub in Northeast China as well as a famous cosmopolitan city. Western architecture was brought to the city along with the European immigrants, and Harbin, in turn, became home to buildings in diverse architectural styles such as Russian traditional, neoclassical, Byzantine, 
Gothic, Renaissance, Baroque, Art Nouveau, and eclectic. As the newly affluent urban populace, the thenemerging domestic entrepreneurs in Harbin's Chinese ghetto 'Fujiadian' viewed those ornate and/or fashionable Western buildings as symbols of wealth and sophistication. Thus, those richer Chinese sought to build 'Western' buildings that can meet their own residential, commercial, and even psychological needs. In this context, the Chinese craftsmen created a hybrid architectural style for their clients, which basically combines the Baroque façade with the Chinese traditional quadrangle (Siheyuan). This hybrid style was later termed 'Chinese Baroque' by the Japanese architectural historian Yasuhiko Nishizawa (1996, as cited in Sheng \& Ueda, 2016a), and 'Chinese Baroque' henceforth became the official name of this architectural style. Daowai District, the current administrative district that covers the former Fujiadian, still accommodates a large number of Chinese Baroque buildings today.

Since 2007, there has been an ongoing heritage-driven urban development project in Daowai District (Cui, Li, \& Ren, 2007; Zhang, 2007). The project aims to revitalise its Chinese Baroque area by transforming the historic area into one of the three largest tourist areas in Harbin, the other two being the Zhongyang Street area in Daoli District and the museum area in Nangang District (Levoshko \& Kirichkov, 2016). To carry out the plan, all the residents living within the area were asked to move out, which caused widespread discontent within the community (Yin \& Wang, 2014). While a small part of the area has been renovated/reconstructed and, in turn, gentrified and transformed into a pedestrian precinct and tourist attraction, many historic buildings are still left empty and even unattended to decay. With archival analysis, observation, and semi-structured interviews, this paper critically analyses the urban exclusion due to built heritage renovation and historic area revitalisation, and investigates the challenges that Harbin is now facing in its urban (re)development. In-depth interviews were conducted in 2020/2021 with the inhabitants of the Chinese Baroque area, locals in wider Harbin society, urban planners, travel agents, and government officials, to understand their perceptions of the exclusiveness and inclusiveness of Harbin's heritage-based urban planning and urban revitalisation.

\section{The Past and Present of the Chinese Baroque Area}

The 1917 Russian Revolution and the consequent fall of the House of Romanov resulted in the official reversion of Harbin to China. In that context, Chinese Baroque architecture flourished along with Chinese business and industry. In the 1920s, a large number of high-quality Chinese Baroque buildings were built in the then Fujiadian. Such buildings comprise a large proportion of the historic urban centre of today's Daowai District, with the majority situated along Jingyu Street [靖宇街] and its side streets (Figure 1). They adapted the highly decorative and theatrical Baroque architecture for the requirements of Chinese everyday lives. Most of the Chinese Baroque buildings are two- or three-storey brick and wood structures, with the ground floor used for commercial purposes and upper floor(s) for residential purposes. In terms of façade, the buildings adopted twisting elements and the often-dizzying array of rich surface treatments of Baroque architecture, thus giving a European appearance. But when examined closely, traditional Chinese architectural decoration themes, such as bat, peony, the Eight Immortals, and the Three Friends of Winter (i.e., pine, bamboo, and plum), are easily noticed on their façades (Sheng \& Ueda, 2016b). As regards spatial organisation, behind the Westernised façades are surprisingly Chinese quadrangles with wooden exterior corridors and staircases. The elaborate decorations on those corridors and staircases are also mainly traditional Chinese (Figure 2). 


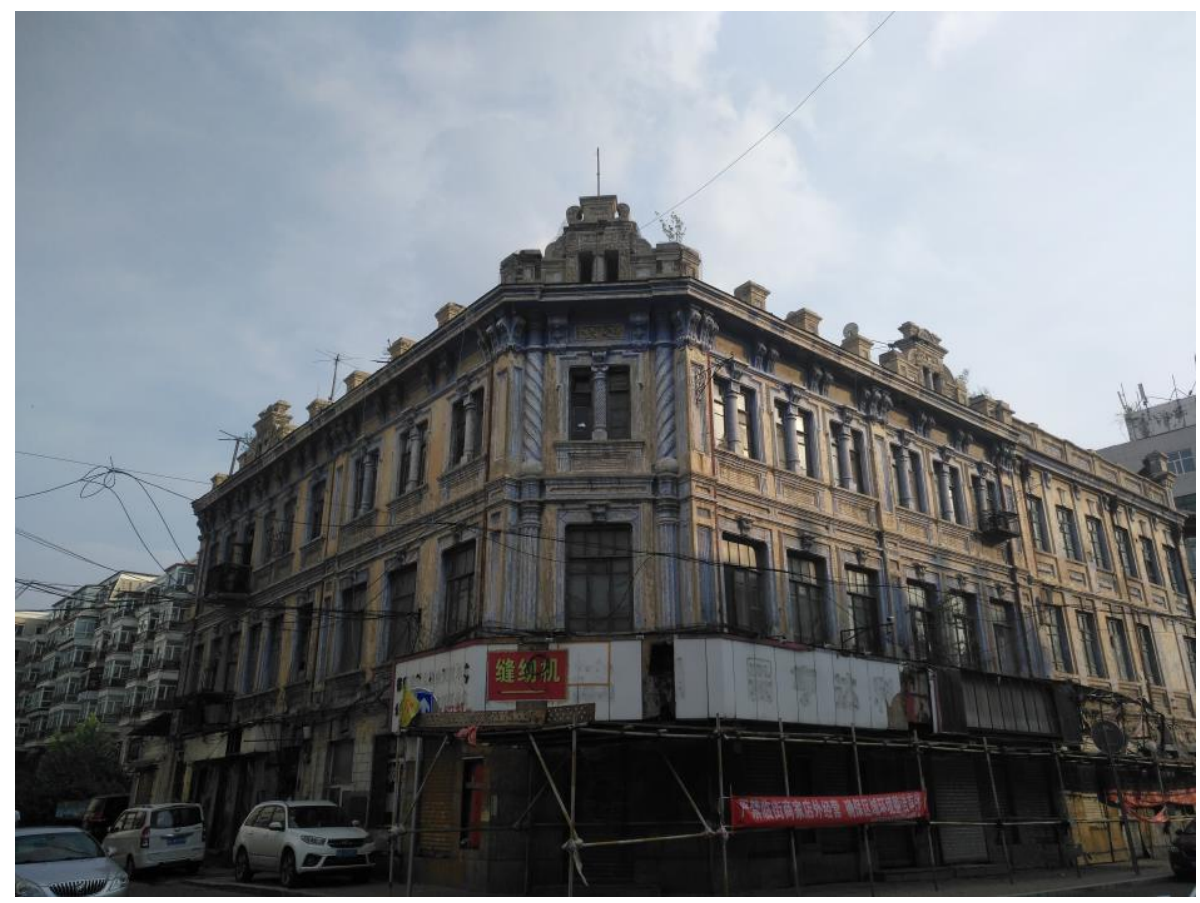

Figure 1. An example of Chinese Baroque architecture. Source: Wenzhuo Zhang, 2021.

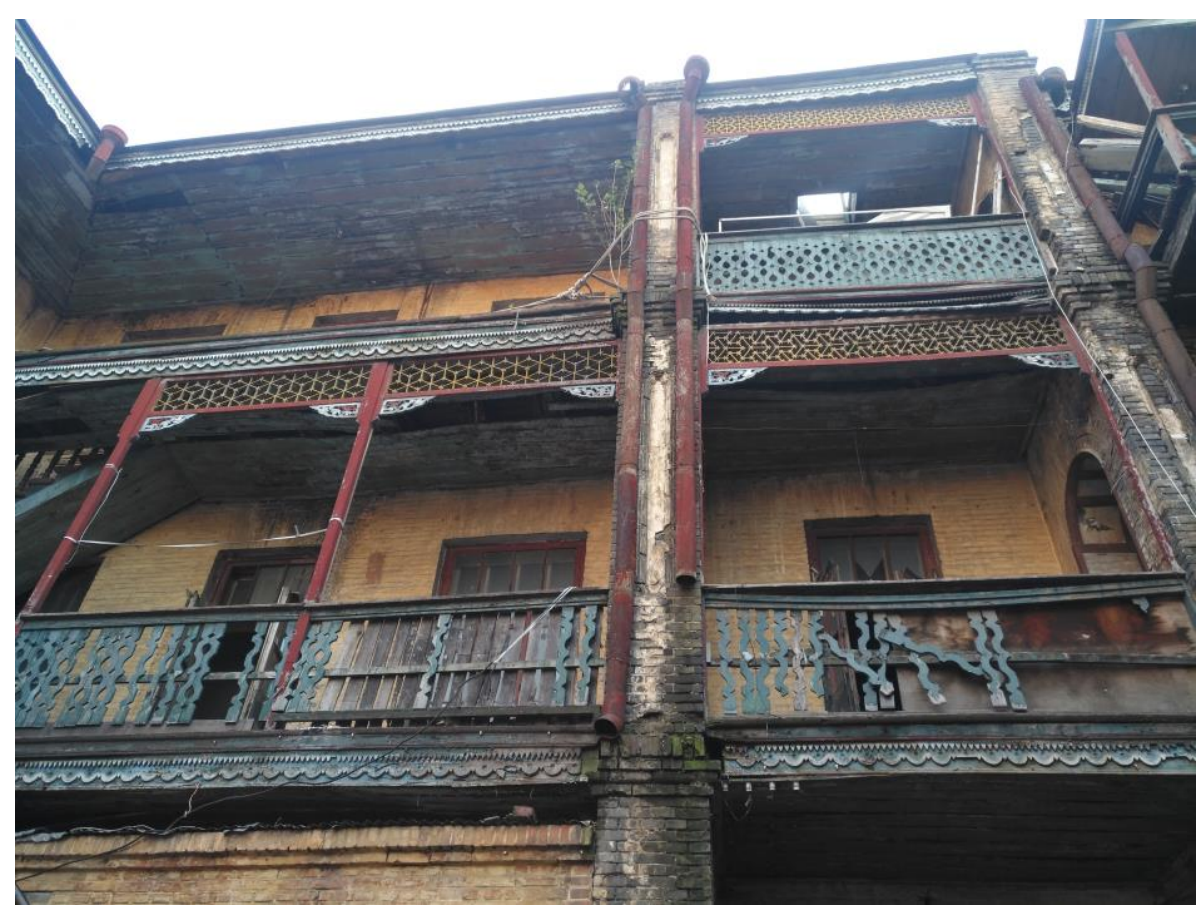

Figure 2. The Chinese quadrangle inside a Chinese Baroque building. Source: Wenzhuo Zhang, 2021.

Once a most prosperous commercial centre of Harbin, Jingyu Street and its surroundings fell into a decline in the 1990s and had become a place with extremely high population density and considerable dilapidated Chinese Baroque buildings by the turn of the century. Lu, Wu, and Guo (2005) reported that the population density of the historic Daowai centre (with the Chinese Baroque area located in its heart) had reached 44.3 thousand people per square kilometre, and the average apartment space per person was only $9.62 \mathrm{~m}^{2}$. Since the wooden floors and staircases have been decaying throughout the past 
century, many of the Chinese Baroque buildings became rickety old houses with poor infrastructure and unpleasant environment, not to mention that those century-old brick and wood structures are not up to standard in terms of fire resistance and pose a major fire risk (Liang, 2001).

\section{The Chinese Baroque Project: Mass relocation, thorough renovation, failed revitalisation}

The Chinese Baroque project dates back to 2007 when the local government decided to renovate and revitalise the 'Chinese Baroque area', an earlier-designated historic area for conservation. Three years later, the People's Government of Harbin Municipality re-demarcated the conservation area and officially named it as 'the Historical and Cultural Neighbourhood of Daowai Traditional Market' [道外传统商市历史 文化街区] (Figure 3). The Neighbourhood covers an area of $47.23 \mathrm{hm}^{2}$, including a $20.27 \mathrm{hm}^{2}$ core zone and a $26.96 \mathrm{hm}^{2}$ buffer zone (Tao et al., 2010). It henceforth became the main arena of the Chinese Baroque project. The Chinese Baroque project is officially divided into three phases. Phase I (started in 2007) and Phase II (started in 2010) were already completed and opened to the public, while the construction of Phase III is yet to start.

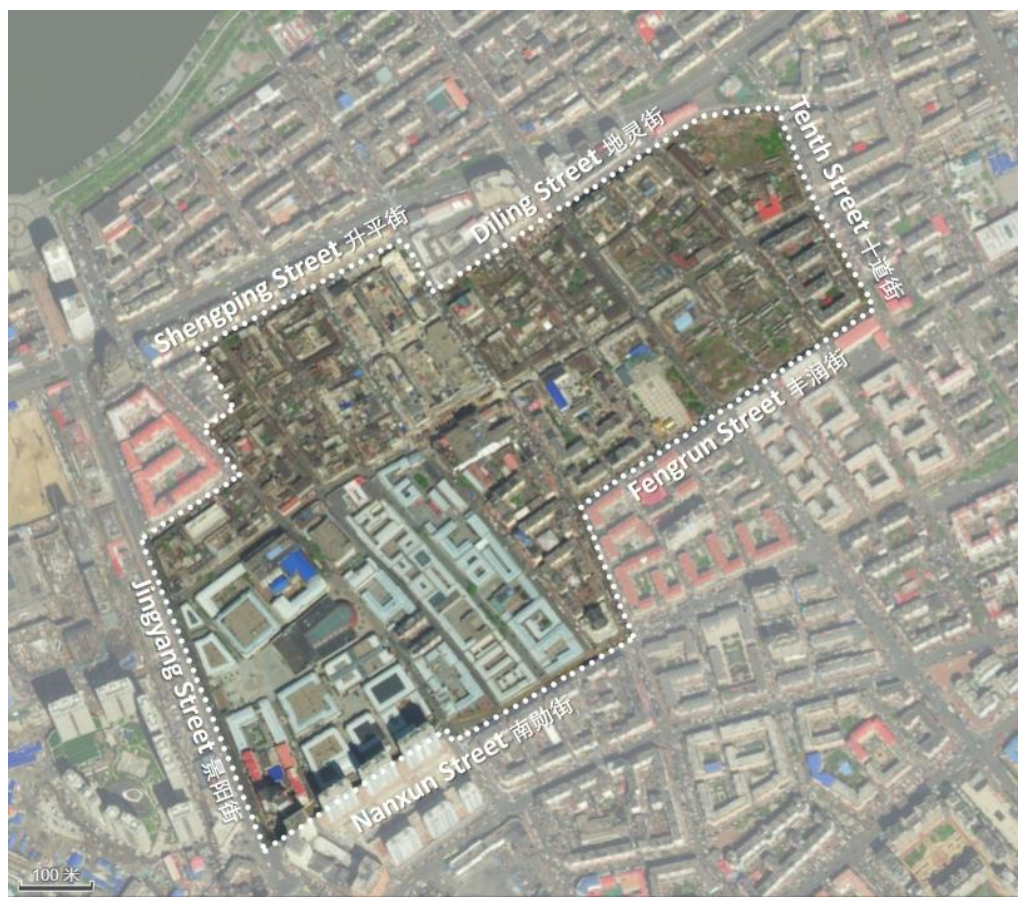

Figure 3. The location of the Historical and Cultural Neighbourhood of Daowai Traditional Market. Source: Wenzhuo Zhang; Base map: Baidu Maps.

\subsection{Inhabitant Relocation for Urban Redevelopment}

Four approaches to urban landscape conservation/renovation were proposed in 2007 for the first phase of this project, namely rehabilitation (i.e., historic buildings in good condition will be repaired and refurbished), reconstruction (i.e., historic buildings that are identified as dilapidated with little rehabilitation value will be demolished and reconstructed according to their original designs), renewal (i.e., as regards historic buildings that have well-preserved façades but severely damaged structures, only the façades will be retained, while the internal structures will be renewed), and development (i.e., nonhistoric buildings which negatively affect the character of the Chinese Baroque area will be demolished, and new buildings that harmonise with their surroundings will be developed on-site) (Zhang, 2007). To 
realise this ambition of heritage-driven urban redevelopment, all the residents within the Phase I area were relocated elsewhere. Obviously, some government officials saw in Phase I the deficiency of mass relocation, for a piece of news published before the completion of Phase I reported that according to some informant from Daowai local government, the subsequent phases of the Chinese Baroque project would not seek mass inhabitant relocation any more. Instead, the renovated historic residences would be returned to their original owners because if all the inhabitants on those historic streets are relocated elsewhere, the historic area will be an empty neighbourhood where tourists can only see old buildings. In that case, even a stylish area will not have much tourist value' (Cui, Li, \& Qin, 2007, n. p.).

However, when Phase II commenced on 1 March 2010, land expropriation and inhabitant relocation were once again conducted. It only took 40 days for all the residents within the Phase II area to move out. Interviewee CB-1 [born in 1975, female] had two small apartments along Jingyu Street, one of which was situated in the expropriation area of Phase II. She agreed to be relocated, handed her keys over to the local government on the first day of expropriation, and received a new apartment in compensation. The compensatory apartment is in the Ceramics Unit [陶瓷小区], a residential area that is west to Jingyu Street and farther away from the city centre than the Chinese Baroque area. But the new apartment is $10 \mathrm{~m}^{2}$ larger than her old one. Interviewee CB-1 thought that although the compensation policy was not as good as the one for her other apartment along the same street which was expropriated several years later, it was still fair considering the very bad condition of those old buildings. However, some residents thought otherwise at that time. They refused to hand over their apartments and accept the compensation offered by the government, but demanded more compensatory payment and/or larger compensatory apartments. Interviewee CB-1 recalled that those uncooperative inhabitants were 'finally arrested' by the government and were only released when they agreed to move out: 'it was some ten years ago, at that time it was not as democratic as it is today'. The Conservation Plan of the National Famous Historical and Cultural City of Harbin (2011-2020), which was completed in September 2010 and approved by Heilongjiang provincial government in 2012, planned that Jingyu Street and its three side streets (North/South First Street, Second Street, and Third Street) would be transformed into pedestrian streets, in order to keep their traditional features and create some attractive public space. Moreover, it was planned to develop a 'traditional market' themed precinct by completely transforming the relevant mixed-use land to commercial land, that is to expropriate all the residences within the area between First Street and Fourth Street and relocate those residents elsewhere. In this context, it was without doubt that all the inhabitants within the Phase III area would also be relocated.

Yin and Wang (2014) interviewed the people who lived in the Phase III area about their perceptions of the land expropriation and inhabitant relocation, and reported that they resisted the relocation mainly for concerns about the quality of life. Those inhabitants heard that the government planned to relocate them to Qunli, a suburb that was then regarded to be underdeveloped and very far away from the city centre. In that case, they did not want to move out of the much more developed Chinese Baroque area and 'turn from a citizen to a villager' (p. 26). Unexpectedly, the Phase III expropriation soon came to a halt and has not been completed until now. Interviewee CB-2 [born in 1961, male] has an apartment in the Phase III area and refused to hand it over to the local government when he had the chance. He said regretfully when talking about his reason for resisting expropriation: 'At that time, that place [where the government planned to relocate us] was in the middle of nowhere. Nowadays it is indeed a very good location'. Interviewee CB-2 explained that the residents who refused to move had various reasons: some wanted a compensatory apartment in a better location, some wanted more money in compensation, and some have personal reasons such as a dispute over property rights. He also conceded that there were residents who wanted to take advantage of 'the party state's expropriation' and went too far in demanding compensatory money at that time. It is noteworthy that the reasons for their refusal to be relocated are all closely linked to their economic demands rather than cultural/social demands, in which case they easily changed their mind when they realised that the 
compensation cannot be further negotiated and was actually reasonable considering the condition of their very old and even cracked buildings. Thus, those residents who were left behind initiated a relocation request a few years after the expropriation paused. Nonetheless, they never got a second chance of handover, as the local government declined their request because of funding restriction. By now, it has been over five years since the Phase III expropriation officially started in May 2016.

Today, most of the Chinese Baroque buildings within the Phase III area are vacant. The buildings that have not been handed over to the government are no exception - most residents have moved out of those decaying buildings because the buildings are now on the verge of collapse and are too dangerous to live in. The area thus became a 'ghost city' with a large number of shabby old buildings and very few residents. People who are still living there are generally too aged and/or too poor to leave the place. Interviewee CB-3 [born in 1953, male] is one of them. He has been living in a Chinese Baroque building on North Third Street for over 40 years and has witnessed the ups and downs of the area. Interviewee CB-3 was not able to clearly explain why the government postponed the expropriation of his apartment and did not have much idea about what would happen to his living place and the broader area in the future: 'The building where I am now living will certainly be repaired. It cannot be demolished. But they [means "the government"] never told us how they will demolish or repair these buildings'. When asked about his expectation of the Chinese Baroque area in the future, he roughly said that he hopes the area 'can be better than it was before' but did not articulate his thoughts. Like the many other residents in the Chinese Baroque area, Interviewee CB-3 cares most about his own living condition and is interested in the location and quality of his residence rather than the cultural inheritance of the historic neighbourhood. Ignoring the question about his perception of the renovated Chinese Baroque precinct in terms of architectural authenticity, he instead expressed his disappointment that several of the best restaurants on North Third Street have moved southwards into the renovated precinct, feeling that this moving made his daily life less convenient.

\subsection{A Gentrified Neighbourhood without Residents}

While the old buildings in the Phase III area are still waiting for renovation (or demolition), the Phase I and Phase II areas have been thoroughly renovated, but in a very radical way. Some historic buildings were completely demolished and reconstructed. Many others only have their façades or four outer walls kept, and everything behind those was demolished and constructed anew. When the renovated area was opened to visitors as primarily a tourist attraction, there were only brand-new 'old buildings' accommodating shops and restaurants (Figure 4, 5). Many Harbin locals have visited this renovated Chinese Baroque precinct as it is widely promoted through mass media. Predictably, quite a few local people frowned upon the historic buildings which appear 'too new' and 'too commercial'. Interviewee HL-1 [born in 1970, female] thought the precinct was 'just so so' because the current buildings 'are replicas', or even if some historic buildings were partially retained, the newly added parts 'do not look real': 'I hope those renovated buildings look as old as the original ones. If they appear very new, they don't look like [historic buildings]... thus the feeling changes'. This idea was echoed by Interviewee HL-2 [born in 1981, male], who thought the precinct has lost its historical character because of the 'reconstructions': '[the buildings in the renovated Chinese Baroque precinct] are obviously newly constructed. The feeling of history is not as strong as before'. Similarly, Interviewee HL-3 [born in 1959, female] recalled her childhood memories about the bustling Chinese Baroque area and felt sorry about its current situation: '[the renovated precinct] does not have a feeling of the past. [...] Now it is a tourist attraction, but unfortunately, a tourist attraction without people!' She felt the Chinese Baroque area without its 'authentic liveliness' is 'like a vase only for watching'. Likewise, Interviewee HL-4 [born in 1967, male] succinctly described the precinct as 'bland': 'the essence of Chinese Baroque architecture has gone'. 


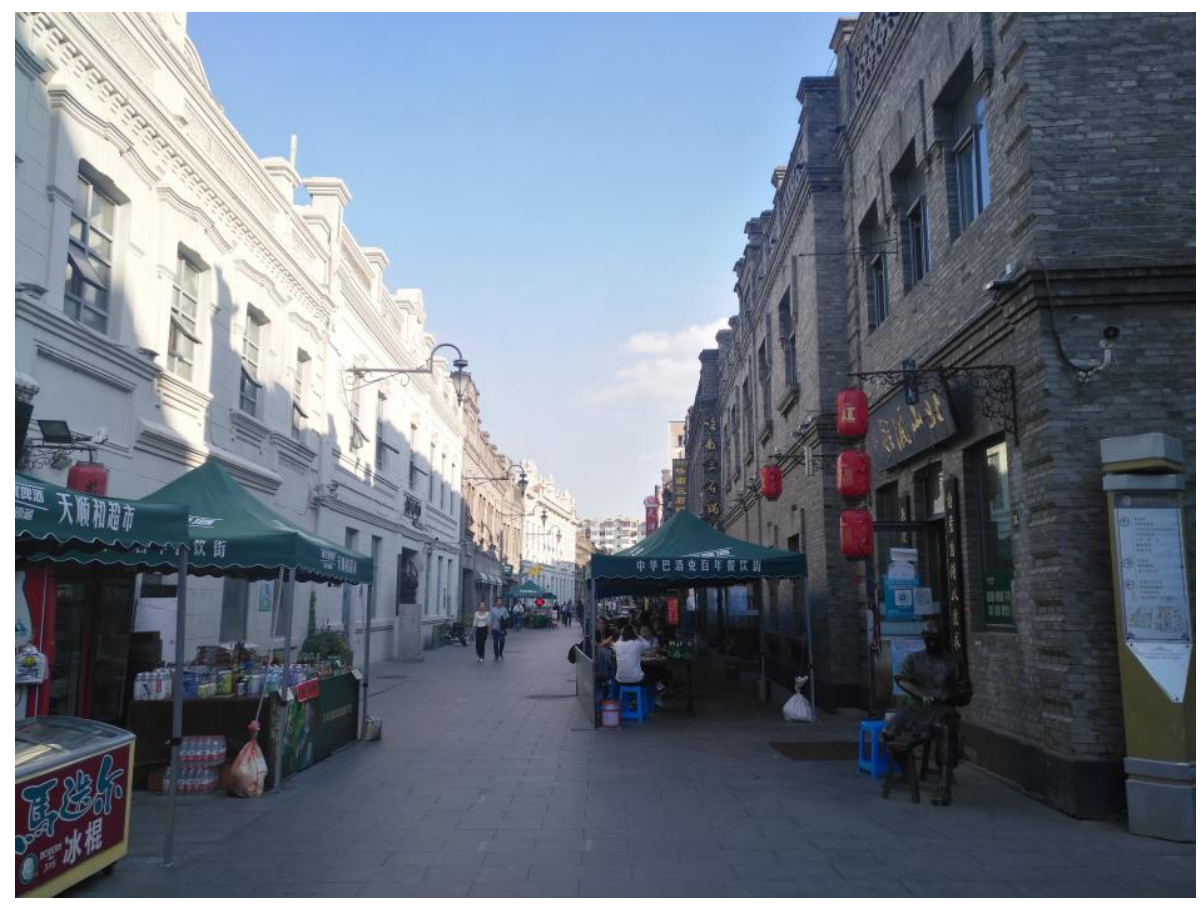

Figure 4. The renovated Chinese Baroque precinct. Source: Wenzhuo Zhang, 2021.

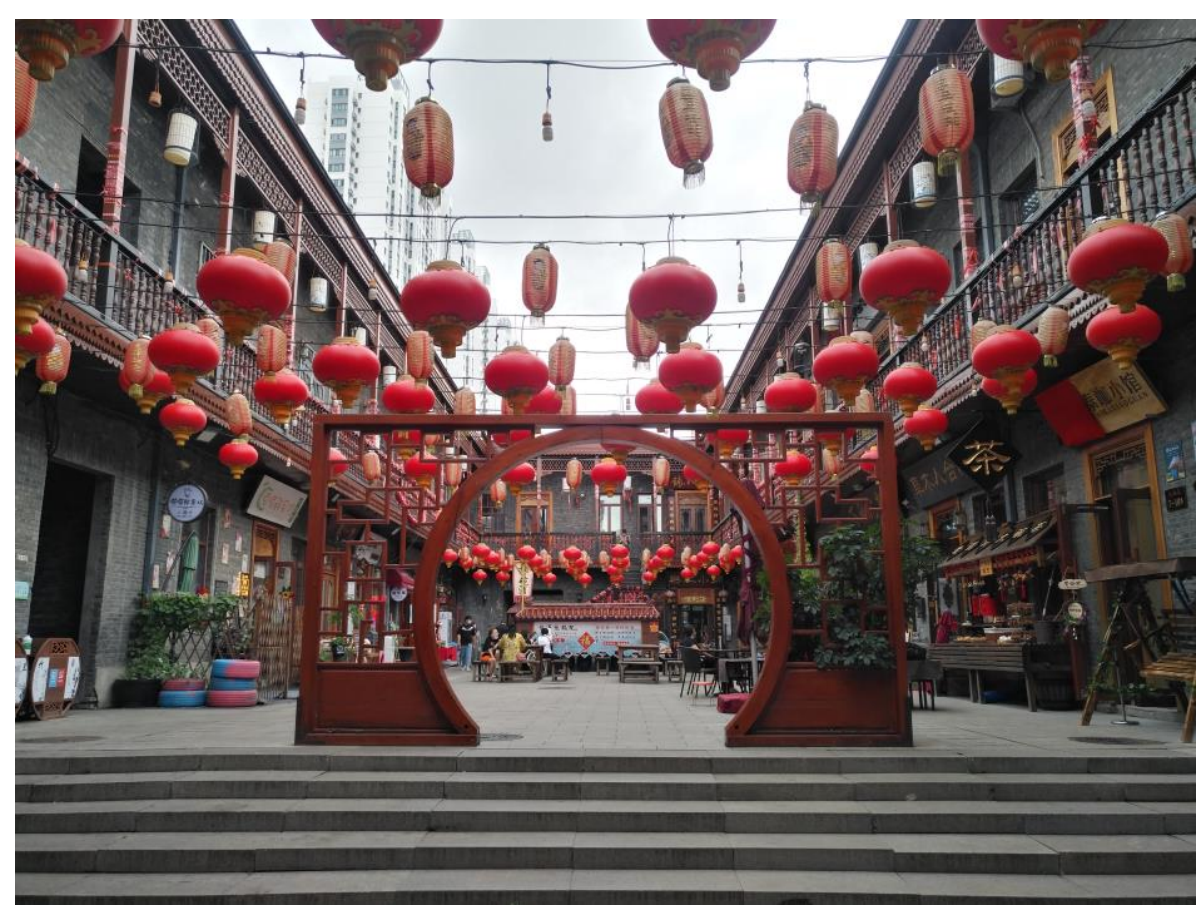

Figure 5. The quadrangle of a renovated Chinese Baroque building. Source: Wenzhuo Zhang, 2021.

For the same reason, although the precinct was redeveloped mainly for tourist purposes, some travel agents hesitate to promote it. Interviewee OF-1, manager of a major travel agency located in Harbin, said that his company did not recommend the Chinese Baroque precinct to clients, because the renovated Chinese Baroque buildings lack historical significance and failed to address the substance of the Chinese Baroque area: 
'The "soul" of the Chinese Baroque area was not represented or even recognised. The buildings are only constructed and shown as images. Restaurants were introduced [into the precinct] when it [means "the redevelopment project"] had difficulties in attracting businesses. [...] [But] the Chinese Baroque area is not only about the material buildings.'

This is somewhat an echo of the concern expressed by the Daowai government official in the 2007 news article. As the gentrified Chinese Baroque precinct is not well-accepted by the public, the business there is not good. Interviewee CB-3 observed that the once flourishing restaurants on North Third Street have been struggling since they moved into the renovated precinct in the southern part of the area. Interviewee CB-2 reported that 'many restaurants there were finally closed because it is too expensive [to eat in those restaurants]'. The current COVID-19 pandemic significantly reduces the number of visitors, which makes the situation even worse - the businesses in the precinct rely almost exclusively on visitors because inside this renovated precinct there is no resident at all.

\section{Is Heritage-driven Urban Redevelopment a Cultural or Economic Issue?}

It seems that the heritage-driven redevelopment of the Chinese Baroque area is unsuccessful from every aspect: the local inhabitants were forced to move out of the area, the initial phases of the project were completed but did not really achieve the objective of urban revitalisation, and an even larger piece of land within the area is still left unused along with its dilapidated buildings. But it is too easy to say that the project is just a mistake. Urban planners who are closely involved in the urban regeneration practices of Harbin generally feel pity for the current situation of the Chinese Baroque area. However, they do not think it is simply the result of an urban planning/management failure. Interviewee UP-1 thought it is a pity that the renovated Chinese Baroque precinct only retained memories of the historic buildings, while the former lifestyle was completely erased from that neighbourhood. He nevertheless pointed out that urban planning only offers a possible solution in such cases: 'decisions about heritage management are not made merely from our [means "urban planners'"] perspective. [...] Damage and renewal can hardly be avoided in the urban development process'. Interviewee UP-2 further posed the question of whether urban redevelopment focusing on daily lives or that focusing on business/consumption is more suitable for Harbin, or more specifically, for its Daowai District:

'When I was a student, I didn't regard mass commercially oriented renovation and commercial expansion as a good way for local governments [to achieve urban redevelopment and revitalisation]. Having been a practitioner for so many years, now I have realised that the local governments, especially those high-ranking government officials, can understand a district so deeply that their knowledge is perhaps beyond my imagination. It needs investigation as to whether Daowai District needs more internal or external impetus [to revitalise its historic centre]. Before we have an answer to this question, I cannot say which approach to urban regeneration is better.'

Not only do urban planners think that the Daowai local government just did what it had to, some former inhabitants of the Chinese Baroque area also have similar opinions. Interviewee CB-1 thought that the infrastructure in their new residential area is much better than that in the historic urban centre, and their daily lives are very likely to be disturbed if they still live in the Chinese Baroque area when it is successfully transformed into a commercial area:

'It is surely not economical for the reconstructed [Chinese Baroque] buildings [...] to be used for both commercial and residential purposes. [...] The problem is that the area was not successfully revitalised in the subsequent years and has stagnated. 
Without enough visitors, it looks deserted. If some residents were kept in the area at the time of relocation, there could still be liveliness in that place even when the project failed - at least some people are living there! Now the precinct looks vacant as all its residents are gone. Nonetheless, I think the initial strategy of relocating all the inhabitants and transforming the area into a commercial area was not wrong, only that they failed to successfully develop this commercial area.'

Interviewee OF-2, the former deputy director-general of Harbin Urban and Rural Planning Bureau, once worked in the headquarters of the Chinese Baroque project. He attributed the Chinese Baroque area's predicament primarily to the economic problems of Daowai District and the broader Harbin city. Comparing Harbin with Shanghai, where heritage-driven urban redevelopment projects are generally very successful, Interviewee OF-2 highlighted that Shanghai has a much stronger economy: 'The economic gap between Shanghai and Harbin is huge. [...] Although our government was well-prepared at the initial stage, the historic area can be revitalised and reused only if it is accepted by the market and receives their investments'. He thought the main difficulty faced by the Chinese Baroque precinct now is that private capital has not been successfully channelled into the area because those capitalists are not willing to take the potential risk of the relatively long payback period.

To a large extent, the heritage-driven urban redevelopment project of the Chinese Baroque area is an economic game, despite that the project has strong cultural and social dimensions. On the one hand, the local inhabitants within the area hope to get the most out of the relocation, so that they can live better lives after their handover of the historic buildings. On the other hand, the relevant governmental sectors are trying their best to attract investments and tourists, not only to make profits and revitalise the once impoverished neighbourhood, but also to recoup the high initial outlays of the local government itself. The Chinese Baroque area with an extremely high population density and poor living environment undoubtedly requires urgent and serious work for its redevelopment and revitalisation. Considering the relatively poor economy of the deindustrialised Harbin, the current local government seems to have few choices to deal with this problem. The key to making this project more inclusive and, in turn, achieve a win-win situation is not only to keep and collaborate with (at least some of) the inhabitants of the Chinese Baroque area, but also to consult widely with the broader society of Harbin on what is the most suitable business model for the area and how to best attract the target visitors and investments. Moreover, an overall economic upturn of the city is also of vital importance for the revitalisation of its historic urban centre, which requires systematic economic reform and management.

\section{References}

Cui, S., Li, B. and Qin, L. (2007) 'No More Mass Relocation in the Transformation of Chinese Baroque Area [中华巴洛克街区改造不再大规模腾迁]', Harbin Daily, 30 October [online]. Available at: http://news.sina.com.cn/o/2007-10-30/011112807998s.shtml (Accessed: 26 August 2021)

Cui, S., Li, B. and Ren, Q. (2007) '187 Households Moved out of the Chinese Baroque Area (Daowai District, Harbin) on the First Day [哈尔滨道外中华巴洛克街区 187 户首日腾迁]', Modern Evening Times, 19 June [online]. Available at: http://heilongjiang.dbw.cn/system/2007/06/19/050859096 .shtml (Accessed: 26 August 2021)

Gamsa, M. (2010) 'Harbin in Comparative Perspective', Urban History, 37(1), pp. 136-149.

Koga, Y. (2008) “The Atmosphere of a Foreign Country": Harbin's Architectural Inheritance' in Cronin, A. M. and Hetherington, K. (eds.) Consuming the Entrepreneurial City: Image, Memory, Spectacle. New York: Routledge, pp. 221-253. 
Lahusen, T. (1998) 'A Place Called Harbin: Reflections on a Centennial', The China Quarterly, (154), pp. 400-410.

Levoshko, S. and Kirichkov, I. (2016) 'Tourist Quarter "Chinese-Baroque" of Dao Way District in Harbin City: Experience, Problems and Perspectives of Renovation', MATEC Web of Conferences, 73 [online]. Available at: http://dx.doi.org/10.1051/matecconf/20167306003 (Accessed: 1 August 2021)

Liang, W. (2001) 'A Highlight of Harbin Modern Architecture: Chinese Baroque Architecture [哈尔滨近代建 筑的奇苑—— “中华巴洛克” 建筑]', Journal of Harbin University of Civil Engineering and Architecture, (5), pp. 98-102.

Lu, M., Wu, S. and Guo, E. (2005) 'Practice of Traditional-style Conservation Area Revitalisation: Taking the Detailed Regulatory Plan of Harbin Daowai Traditional-style Area as an Example [传统风貌保 护区复兴实践一一以哈尔滨道外区传统风貌区控制性详细规划为例]', City Planning Review, (11), pp. 91-94.

Sheng, Y. and Ueda, A. (2016a) 'History and Present Situation of Traditional Building Decoration in Harbin, China: Succession of China Western Architecture of Daowai District in Harbin (1) [ハルビン市道外 区の伝統建築にみられる装飾文様の歴史と現状一中国ハルビン市道外区靖宇街周辺の中国式西洋 建築の維持・継承に関する調查・研究(1)]', Bulletin of Japanese Society for the Science of Design, 63(3), pp. 63-72.

Sheng, Y. and Ueda, A. (2016b) 'Characteristics of Traditional Building Decoration in Harbin, China: Succession of China Western Architecture of Daowai District in Harbin (2) [ハルビン市道外区の伝 統建築の装飾文様に表出した生活文化一中国ハルビン市道外区靖宇街周辺の中国式西洋建築の維 持・継承に関する調查・研究(2)]', Bulletin of Japanese Society for the Science of Design, 63(3), pp. 73-82.

Tao, Y., Liu, Y., Jia, Y., Sun, M., Wu, L. and Liu, L. (2010) Instruction Book for the Conservation Plan of the National Famous Historical and Cultural City of Harbin [哈尔滨市历史文化名城保护规划说明书]. Harbin: People's Government of Harbin Municipality.

Wolff, D. (1999) To the Harbin Station: The Liberal Alternative in Russian Manchuria, 1898-1914. Stanford: Stanford University Press.

Xie, L., Yang, Z., Cai, J., Cheng, Z., Wen, T. and Song, T. (2016) 'Harbin: A Rust Belt City Revival from Its Strategic Position', Cities, 58, pp. 26-38.

Yin, H. and Wang, X. (2014) 'Culture Dying in Urban Historical Block Modification Works: A Case Study of Historical Block of Daowai in Harbin [城市历史街区改造中的 “文化之歾” ——以哈尔滨市道外历史 街区为例]', Modern Urban Research, (6), pp. 22-30.

Zhang, F. (2007) 'Four Ways to Renew the Chinese Baroque Buildings [四种方式更新中华巴洛克]', Modern Evening Times, 4 August [online]. Available at: http://news.sina.com.cn/c/2007-0804/020412323963s.shtml (Accessed: 26 August 2021) 